\title{
Grameenphone Faces Problem in Rural Economy - A Case Study
}

\author{
Muhammad Rehan Masoom*
}

\begin{abstract}
Telecommunication industry is one of the most dynamic and vibrant sectors, especially for the developing nations that have a huge population. However, unlike the developed nations, the infrastructure and the political scenario of the developing countries, indeed, posits various challenges. The expansion of multinational businesses requires becoming aware of not only the cultural differences, but the governances with proper emphasize. The case study deals with the recent SIM Tax issues and underlines the prospect of 'Mobile Operators' in the rural economy of Bangladesh.
\end{abstract}

Keywords: Telecommunication industry, SIM tax, Rural marketing, Rural banking.

\section{Introduction}

"Definitely, there is a big market in the rural area. So, we are focusing on it," Anders Jensen, chief executive officer of Grameenphone, said this while he and some other high officials of Grameenphone were visiting Boro Koyer village in Gazipur in

* Assistant Professor, School of Business \& Economics, United International University, UIU Bhaban, Dhaka 1209, Bangladesh; rehan_1611@yahoo.com 
April 20081. The primary purpose of the visit was to know about the village people's communications needs, their experiences with mobile telephones, and how or what Grameenphone could do to meet their communications needs. GrameenPhone has become the leading wireless operator in Bangladesh, with a network covering over 90 percent of the population. The Village Phone Program has had a significant impact especially on the rural population of this low-tele-density country. (See Exhibit Four for the highlights of what GrameenPhone has done in rural areas). The country's leading mobile phone operator eyes more on increased number of customers in rural areas, as the company believes its future growth lies in rural areas. "We learn first about the need of villagers then we will decide what we could offer," he said. He said in the light of livelihood of rural people GP is planning cost effective mobile services for them.

\section{The Rural Economic Structure of Bangladesh}

\section{1) Rural Market Dynamics}

With more than seventy percent of its population residing in the rural areas, it would not be wrong to describe Bangladesh as a giant village. Considering that $64 \%$ of the rural population are below the age of thirty and 77 percent of the total population were born after the War of Liberation, i.e., after 1971, it can be safely concluded that it is the youth of today who are fueling the engine of growth ${ }^{2}$ Abdul Bayes, indicated that as information flow increases due to the expanded mobile phone coverage, the cost of crop marketing is expected to decrease, particularly in remote areas where potential marketing gains from the increased information

1 Star Business Report, entitled "Grameenphone zooms in on rural areas" Published in the Daily Star on 2008-04-24.

2 Dr. Khalid Hasan, the Managing Director of Nielsen Bangladesh (also the Treasurer of AmCham Bangladesh) published in The Daily Star Suppliment titled Forum (Volume 3 Issue 10). Article title, “The Village Vive" published in October 2009. 
flow is large ${ }^{3}$. He highlighted some very interesting points. First, every farmer need not possess a set. It could be the community, producers' organizations and others from where the price information could spread, either as a "public good" or as a "private good." A participant from the audience in that seminar informed us that in his village in Africa, a mobile phone is hung from the branch of a tree and interested persons could use it on payment of a fee. Second, even with access to mobile phones, full gains might not be reaped as farmers might need more information. The role of public authority and media in this respect is very important. Again, producers' organizations could form an information forum of their own to be more effective at bargaining than individual initiatives. Bayes said that, "we indeed find that the network expansion has a larger impact in market participation in areas farther away from the district centers than in closer areas".

About 40 percent of the rural households in Bangladesh are reported to have access to mobile phones and roughly one-fourth of the users are poor. Rickshaw pullers, fishermen, traders all use it to minimise information irregularity and quicken communication between two points 4 . Out of 150 million people, about 50.4 million people have access to mobile phones. The market is still dominated by Grameenphone, with roughly half of the market share, and the rest is distributed among 5 other companies (See Exhibit One for "Mobile Phone Subscribers in Bangladesh"). The tariff rates are gradually going down to a competitive level. The price of mobile sets has come down to an affordable level. It appears that mobile phones are effective not only in terms of reducing marketing costs and price dispersions but also in terms of managing disasters, searching for jobs and improving the quality of life.

${ }^{3}$ Bayes, Abul (2000). The Phone and the Future: An Evaluation of Village Pay Phones in Bangladesh. Published in Global Dialogue: The Role of the Village in the $21^{\text {st }}$ Century.

4 The Daily Star, Article entitled "Phones and Farmers", Published on 24.08.2009. 


\section{2) Impact of Overseas Remittance}

The rural market's share of FMCG (Fast Moving Consumption Goods) has been increasing steadily over the years and it has already outstripped urban demand in the current calendar year. This is a clear indication of the rapid increase in effective demand of the rural consumers compared to that of their urban counterparts. It is, therefore, imperative for market researchers to analyze and understand the nature and dynamics of the fastchanging consumption patterns of the rural consumers. A major factor contributing to their steadily increasing purchasing power is the phenomenal increase in overseas remittance that has registered an almost six-fold increase over the last decade. The nation owes a debt of gratitude to the migrant workers whose hard-earned earnings have contributed significantly towards poverty-alleviation of the nation in general and of the rural masses in particular. A concomitant positive effect of such huge remittance inflows is a significant reduction in income inequality between the rural and urban populations (See Exhibit Two for detail regarding the issue of Remittance in Bangladesh).

\section{3) The Consumer Behaviour of Rural Market}

Various market studies reveal that consumers have their own set of idiosyncrasies and dogmas which are deeply rooted in their cultures. We can, thus, state with conviction that what would work very well for one set of consumers may not work at all for another, even in the same geographical area, because of different ethnic, religious and financial backgrounds. Therefore, before devising a marketing strategy, it is imperative for all marketers to understand the psyche of the target market. One of the major differences between urban and rural consumer is that urban buyer is an individual; he buys his stuff of his own free choice whereas in rural areas the purchase decision-making is largely in groups, a collective decision-making. In the rural environment social approval plays a critical role. Again, the level of literacy is also a big divide. While urban audiences can buy a product after reading product literature, the same is not true of rural buyers. For rural 
audiences, seeing is believing5. In this respect, the rural Consumers may be divided into three distinct categories:

1. The educated, upwardly mobile, middle-income, mediasavvy category, with high aspirations and considerable purchasing power, who are in many ways comparable to the urban population;

2. The segment of the rural youth who have attained "medium level" ( SSC or HSC) education and who have got some exposure to urban lifestyle (frequent visits to the urban areas, access to modern amenities such as TV, mobile phone, motor cycle, etc.);

3. The ultra-poor illiterate masses who are inaccessible to the mass media (media-dark).

\section{4) Buying Process and the Predominant Role of the Rural Youth}

Praveen Kashyap, in Rural Marketing, has rightly pointed out that the rural people may be illiterate, but they are by no means unintelligent. Due to increasing media reach, aggressive advertising campaigns and frequent inter-personal communication which is comparatively more common in the rural areas, rural consumers are quite familiar with the various products and services available in the market. Basically, the buying process involves:

1. Awareness of products and services through TV, radio and, to a lesser extent, newspapers; the youth, who are often the first-generation literates, assimilate more from such exposure because of their enthusiasm and education.

2. Through frequent visits to urban areas (for entertainment, treatment of elders or employment), they are exposed to various brands of products and services.

3. They, then, share their ideas with their peers and/or rural opinion leaders. 
4. These informal discussions help the rural consumers to reach well-informed decisions on, not only product, but also brand selection.

The marketers/advertisers, while devising their campaign, should avoid random or "hypothetical" assumptions about the rural consumers and carefully consider the following:

i. What do our rural population use (lifestyle)?

ii. What do they buy and why (brand specific)?

iii. The extremely important role of the "youth opinion leaders" in the buying process.

\section{The SIM Tax Issue}

The telecom industry in Bangladesh is at the forefront of discussion and debate. On one arm of the scales is the potential of the industry and the burden of SIM tax and handset duty is on the other. After the mobile technology has conquered the urban population, it is a logical next step now to stride into rural regions. But most mobile operators believe the SIM tax is the main reason they are still in the red and hindering rural takeover. The Daily Star roundtable discusses the issues of this industry and the path to a 'Digital Bangladesh' by 2021. The six mobile operators added around 46.41 million customers as of May 2009 (See Exhibit One for the number of Subscribers of Six Operators). However of the total market, top three operators -- Grameenphone, Banglalink and AKTEL -- hold more than 90 percent share. Citycell, TeleTalk and last entrant Warid are the bottom three players. Except Grameenphone no other operators are in profit, which compelled all the operators not to subsidise SIM tax. In such cases merger, consolidation or closure would be the solution. 


\section{The Discussion ${ }^{6}$}

Mahfuz Anam, editor of The Daily Star, stated that "Our future growth lies in the rural area. So any rationale for any cost cutting to penetrate the rural areas is the biggest justification. The real beauty of the mobile industry is that it is far bigger than its own economy. It is cultural, it is educational, it is heath, it is interpersonal, it is keeping yourself in touch with your friends and relatives, and listening to music that you like. It has a far bigger dimension." He also said, "I think we have failed to appreciate ... the enormity of the technology and diverse opportunities that it provides. That, I think, has also been a failure of the media. We are talking about political empowerment. Barack Obama practically won his election over the mobile telephone. He earned so much of his election funding through mobile connectivity. The internet in mobile phone played a very big role in his election." "The VoIP incident damaged your image a bit. Our next target is expanding the telecom service into the rural areas," the editor added. "It is linked with our vision of Digital Bangladesh, it is linked with our progress and it is linked with our becoming far more democratic society than we have been before. There are many dimensions today." Nobel laureate Professor Muhammad Yunus indicated that VoIP can be used as an effective tool for poverty alleviation.

Debapriya Bhattacharya of Centre for Policy Dialogue (CPD) highlighted three reasons behind the downslide in telecom industry growth in 2008; first, Tax on SIM, second, 'Price War' among competitors and third, the crackdown on illegal VoIP networks.

Oddvar Hesjedal, Chief Executive Officer of Grameenphone indicated that as per the mobile operator's experiences in rolling operations out into rural areas, rural customers are not readily able to bear the taka (Tk) (currency of Bangladesh) 800 per subscriber

6 The Daily Star, Article Titled "Roundtable nn Mobile Sector Growth Prospects, Time for Telecom Players to Go Rural" published in June 22, 2009 
identity module (SIM) cost. Their spending traits differ from that of urban users and they are hesitant to spend even Tk 100 on the mobile phone a month. SIM subsidisation does not warrant that operators recover the money within a short time. It takes one and a half years, or even more, to recover the subsidized money from most rural and certain urban regions. Most interestingly, operators get nothing after bearing the SIM tax, as customers choose to switch to another operator in the meantime. In regards to the myth that mobile operators remit a huge amount of money abroad, Hesjedal said an insignificant amount of money is remitted. In contrast, ample amount of foreign direct investments enter each year into the country through the mobile sector.

Ahmed Abou Doma, Chief Executive Officer, Banglalink indicated that SIM tax contributes to at least half of the losses of Banglalink. He said, "When you see five out of six operators losing money, it cannot be a management problem, nor a strategic problem". He said, "We all belong to different groups and came from different backgrounds with varying management styles. "So there is something wrong in the existing environment of the telecom industry in Bangladesh". He cited a World Bank study, which suggests that Bangladesh has the lowest call rate, which is mainly due to competition and price wars among the six operators. Pointing to the issue of too many operators, he said Saudi Arabia had two operators and introduced a third six months ago. "Why do they have only three operators, despite having purchasing power and a healthy GDP?". The same issue was raised by Ananya Raihan, Executive Director, D. Net. He said that the telecom market is experiencing saturation as the country has too many operators in comparison to the number of potential subscribers, while there is an opportunity to increase the number of subscribers, not all of them can be brought under connectivity. The operators should try and focus more on presenting value added services. He said a differential pricing policy is required to appeal to potential subscribers in rural areas.

Cultural Activist Aly Zaker mentioned the importance of mobile phone as he said that If it were not for cellular phone connectivity, there would have been no way to reach out to the remote villages, not even in the case of medical emergencies. He added e-medical 
services offered by operators have benefited rural Bangladesh. M Rafiqul Islam, Joint Secretary, Ministry of Posts and Telecommunications does not believe that the mobile phone operators would record profits once the SIM tax is withdrawn. There are other factors that make an organisation viable and profitable, such as VoIP crackdown and price wars. Those factors must be addressed simultaneously. He said, "What the government can do is facilitate infrastructure and the private sector. The mobile operators will use that infrastructure. Accordingly, tele-density and other activities will increase in the country". Mr. Islam also indicated that the per minute call charge was Tk 6-7 in 1997, which came down to around Tk 0.75 at present. The tele-density was 0.4 percent at that time, which now increased to 34 percent. As per the ICT policy, tele-density will be increased to 70 percent by 2013 .

Taslim Ahmed, Deputy General Manager, Corporate Affairs, Citycell talked about a critical issue. He said that the SIM tax, borne by the mobile operators but supposed to be paid by the customers, can be seen as a revenue earnings scheme for the government. "We subsidised the tax as we wanted to maintain growth. But we do not wish to subsidise any more, as we now target rural customers. If we pass on this tax to rural customers, a SIM card will cost Tk 800 to Tk 1000, which they will not be able to afford," Ahmed said. He said a large portion of the market would be deprived of the mobile technology. "And if this large segment, the largest share of the pie, will not have access to mobile phones or the latest communication technologies, how do you think the country is going to be digitalised?" The mobile phone is the best vehicle to reach out to people and connect them via voice and data because the telecom industry has the largest infrastructure and network coverage across the country. As such, he said. "It has the ability to convert a million probabilities into realities," he concluded. On infrastructure sharing, Taslim Ahmed said many operators are sharing their infrastructure as per the Bangladesh Telecommunication Regulatory Commission (BTRC) guideline.

Muneer Farooqui, Chief Executive Officer, Warid Telecom International Ltd proposed that the government should impose a monthly surcharge on mobile phone use, instead of SIM tax or 
mobile handset duties. The government receives a one-time payment from the SIM tax, during activation of the SIM. But the government can receive revenue every month if it "puts surcharge on mobile phone use instead of SIM tax and duty on handset." The surcharge could be fixed as a percentage, or Tk 1 or Tk 5 per month, per customer. There are 45 million customers and if each pays TK 5, for example, one can simply do the math to get the result. It would take tele-density to the next level, he said. "We did not expect the duty on handsets. It came as a total shock for all of us." The handset duty could be reconsidered to make them more affordable for the poor. "It's a total no-win situation for all," he said. "If the government withdraws SIM tax, it will be a win-win situation for all of us in the long run."

The mobile phone has changed the lifestyle of urban people to the level unmatched by any other sector, said Ahmed Mushfeq Anam, Managing Director, X-Fer Ltd, and Representative, Nortel Networks Netas. But it will not be possible for rural people to afford connectivity if the proposed duty on handsets is implemented in the next budget, he added. "Now it's time to reach out to rural areas, to give them an opportunity to use the mobile technology," he said. "The government should not impose the duty on mobile phone handsets," because "The revenue output of a rural person is around Tk 2,000 to Tk 3,000 a month." He also suggested the mobile phone operators to share their resources or infrastructure to minimise costs. "Competition does not mean you should have separate resources and infrastructure in the same area. You can use the same resources on a sharing basis and help each other in reducing the cost," he said.

BTRC is trying to provide policy support to the information and communication technology (ICT) sector. The mobile sector phone is not separate as it also provides different IT based services, said BTRC Director Rezaul Quader. BTRC also wants to reduce SIM tax, Quader said. "However, we should also consider that the government needs money." Raihan Shamsi, Chief Corporate Affairs Officer, Grameenphone blamed the SIM tax for the stagnant mobile market. He said after the operators decided to discontinue bearing the SIM tax, the market witnessed a 3.5 percent negative growth in September-October 2008. "Low income groups can afford the 
mobile phone services as tariff was reduced to Tk 0.75 at the end of 2008," he said. "Despite lower tariff, the tax burden on the industry has barred growth." He claimed that in terms of tax burden, Bangladesh is on top in South Asia, followed by Pakistan, Sri Lanka and India. According to him, the mobile industry may penetrate more than half of the population to 56.5 percent or 95 million by 2013 , if the SIM tax is waived in the final budget. The government can earn an additional Tk 5,000 crore by 2013 if the tax is removed. (See Exhibit five for the State of Information Technology is Bangladesh)

\section{Conclusion}

The "luxury" item of the early 1990s transformed into a "necessity" within the span of just one decade. Mobile phone is now an essential instrument for reducing "rural penalty". Organizational strength is a must for empowering the poor and integrating them into the distribution profile. The rural poor, including small farmers and the landless, should be mobilized into collective institutions or in "loosely co-coordinated associations to upgrade their income and consumption levels. $7^{\prime \prime}$ There must be a policy to ensure their access to newly created organizational links that are expected to integrate rural economy to public administration. Surely Bangladesh can boast about the dawn of an unimaginable era of communication for the farmers and the rural poor. The six mobile operators added a mere 0.94 million customers to their networks in the second half of 2008, which is 86 percent less than the same period a year ago. In the second half of 2007 they added 6.65 million customers. Bangladesh has the potential for acquiring more than 55 percent penetration rate in the next five years. A high tax on the telecom industry is baring the development, said the operators. The mobile industry anticipates that the subscriber base will reach 95 million from existing 46 million by 2013 if the SIM tax is waived.

7 Mashreque, MS (1995) Kinship and power structure in rural Bangladesh: a case study. Homeland Press and Publications 


\section{Questions}

1. What should be the Marketing Strategy for Grameenphone to avoid price-war in Rural Sector?

2. Who would be the target customer for Grameenphone in the rural areas of Bangladesh? Justify your answer.

3. What are the top five factors that are hindering penetration into the rural market by Grameenphone?

4. Why GoB Officials do not believe that the mobile phone operators would record profits once the SIM tax is withdrawn? If, they are right, then what would be the strategy for Grameenphone?

5. Is handset Duty hampering Grameenphone Marketing Policy? What can solve this problem?

6. Muneer Farooqui (Chief Executive Officer, Warid Telecom International Ltd) proposed that the government should impose a monthly surcharge on mobile phone use, instead of SIM tax. If this was done, what would be the pros and cons for Grameenphone?

\section{Exhibit One: Mobile Phone Subscribers in Bangladesh}

The total number of Mobile Phone Active Subscribers has reached 50.4 million at the end of September 2009. The Mobile Phone subscribers are shown below:

\begin{tabular}{|l|c|}
\hline \multicolumn{1}{|c|}{ Operators } & Active Subscribers \\
\hline Grameen Phone Ltd. (GP) & 21.98 \\
\hline TMIB (Aktel) & 10.56 \\
\hline Orascom Telecom Bangladesh Limited (Banglalink) & 12.13 \\
\hline PBTL (Citycell) & 1.97 \\
\hline Teletalk Bangladesh Ltd. (Teletalk) & 1.07 \\
\hline Warid Telecom International L.L.C (Warid) & 2.69 \\
\hline Total & 50.4 \\
\hline
\end{tabular}

\section{Source: BTRC}

*Subscribers in Millions

**The above subscribers' numbers have been declared by the mobile operators 


\section{Exhibit Two: Remittances in Bangladesh}

The bulk of the remittances are sent by Bangladeshi migrant workers rather than members of the Bangladeshi Diaspora. Currently, 64 percent of annual remittance inflows originate from Middle Eastern nations. Robust remittance inflows in recent years (annual average growth of 27 percent in FY06-FY08) have been instrumental in maintaining the current account surplus despite widening a trade deficit. This in turn has enabled Bangladesh to maintain a growing level of foreign exchange reserves. The key macroeconomic determinants of remittances in Bangladesh as indicated based on a simple regression exercise, the number of workers finding employment abroad every year, oil price, exchange rate and GDP growth are the key determinants of changes in the level of remittance inflow. The results show that: (1) Each additional migrant worker brings in $\$ 816$ in remittances annually; (2) Every dollar increase in oil price increases annual remittance by nearly $\$ 15$ million; (3) Depreciation of exchange rate by one taka increases annual remittance by $\$ 18$ million; and (4) Remittances are higher during periods of low economic growth.

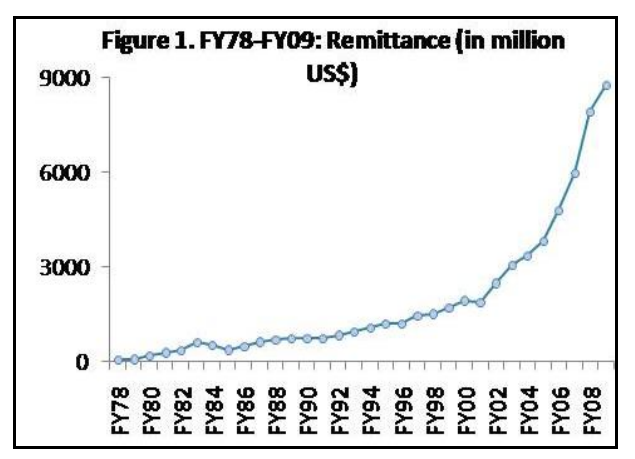

An interesting implication is that the impact of oil price increase on Bangladesh's balance of payment is unfavorable. A dollar increase in oil price increases oil import payments by about \$26 million whereas it increases remittances by $\$ 15$ million. Thus the impact of a dollar increase in oil price on the balance of payments is a deficit of $\$ 11$ million.

Source: Hussain, Zahid \& Farria Naeem (2009) End Poverty in South Asia, Published by World Bank, Retrieved on 5th October 2014. 
URL:http://blogs.worldbank.org/endpovertyinsouthasia/remittancesbangladesh-determinants-and-2010-outlook-0

\section{Exhibit Three: History of Mobile Telecommunication Sector in Bangladesh}

At the time of appraisal in 2000, Bangladesh had one of the lowest tele-density rates in the world: 0.26 telephones per 100 inhabitants. The fixed line incumbent, the Bangladesh Telephone and Telegraph Board (BTTB) had only 350,000 lines in service for a population of 125 million. The waiting list for a fixed line totaled 200,000 subscribers with a waiting time of over 10 years. The challenge was to (i) increase access to telecommunications services and improve the quality of service being offered; (ii) increase connectivity to rural areas, which, in turn, would promote the economic development of rural Bangladesh.

During the 1980s through the 1990s, widespread reforms took place in the telecommunications sector due to various sector-specific, economic and political reasons. Historically, the telecommunications industry has long been a highly regulated monopoly dominated by a state-owned telecom organization. The advent of mobile phone technology has given a unique opportunity for countries to have an alternative source for telecom service. The relatively lower start-up costs, easy accessibility, and suitability of any geographic location for a mobile network helped mobile telephony to become popular quickly.

Bangladesh is the pioneer among LDCs, opening its mobile phone sector for private and foreign investment in 1989. Pacific Telecom launched the country's first mobile phone service. Subsequently, three more mobile phone licenses were issued, in 1996, 2004 and 2005. The opening up of the mobile phone sector by Bangladesh was done independently, not as part of an international agreement. Liberalisation of trade and investment independently, without any binding from any international agreements, is known as Unilateral Liberalisation. The liberalisation of the mobile phone sector of Bangladesh has, thus, been a unilateral one. No LDC has liberalised the sector before making formal commitment in the WTO. 
An examination of telecom literature reveals that the inefficiency, poor service quality, monopoly tariff rate, and inability of the BTTB to meet huge pent-up demand created ample market opportunities for mobile phone. WTO trade policy review (2006) reveals that the call completion rate of the BTTB was below $50 \%$. The waiting time to get a connection was more than 4 years. This abysmal picture of the telecom sector made the policy makers feel the need for alternative source of telecom service for the consumers. The poor performance and inability of the BTTB also made potential users (especially business users) put pressure on the government to open the sector for private sector participation.

Other factors that helped in opening up the sector include the advent of mobile phone technology, and recognition by policy makers of the importance of private sector involvement in promoting infrastructure development, and attracting FDI, in the country.

As telecom services are used as a key intermediate input into production in all sectors, improvement of the sector and the resultant cost reduction upgrades overall productivity and encourages FDI. The urge for attracting FDI in the telecom sector, as well as other sectors, has been a key determinant in liberalisation of the sector.

The unique features of the mobile phone, such as 24-hour availability, instant messaging, Internet access, photography, etc, have been compelling factors that created the demand from all sections of people.

Mobile networks fit the needs of some geographical areas where installation of fixed line networks proves difficult. All these benefits associated with mobile phone service paved the way for the liberalisation of this sector.

Source: The Daily Star Article entitled "Liberalisation of the mobile phone sector in Bangladesh" by Mohammad Abu Yusuf and Quamrul Alam Published on 15.11.2007. 


\section{Exhibit Four: The Contribution of GrameenPhone}

1. The Village Phone Program, operated by GrameenPhone, currently provides mobile phone services to approximately 50 million people in villages across the country. It leverages micro-loans from the GrameenBank, providing women with credit to buy cell phones from GrameenPhone. The women then provide mobile pay phone service in their shops, the local market, and elsewhere, charging a markup agreed on with GrameenPhone. Extended cell-phone coverage in poorer areas has had a tremendous social and economic impact on the operators -- mostly rural, poor women for whom income-generating opportunities are rare. GrameenPhone has also established 500 Community Information Centers (CIC) where citizens in rural areas have access to the internet and information services. GrameenPhone currently has 6,000 sites in all 64 Districts, covering approximately 95 percent of the total population and 80 percent of the country. (Coverage $=$ access to the network signal)

2. Prices have fallen considerably. A prepaid minute of call from a mobile phone cost 5 Taka in 2004 (Exchange rate: US\$1 = approx.. 70 Taka). The rates for the same call have fallen to Taka 1.50 per minute today, due to increased competition and improved interconnection arrangements between operators. With the entry of a fifth operator into the market on May 10, 2007 prices are expected to fall further and more innovative service offerings will be available to customers.

3. The Tele Commons Development Group ("TDG") of Canada found that the consumer surplus from a single phone call to Dhaka, which replaces a physical trip to the city, ranges from 2.64 percent to 9.8 percent of the mean monthly household income. The cost of a trip to the capital ranges from 2 to 8 times the cost of a single phone call.

4. A 2006 Ovum study found that almost a quarter of a million Bangladeshi depend on the mobile industry, directly and 
indirectly, and that mobile services contribute US $\$ 650$ million to the economy every year.

Source: World Bank report titled, "Mobile Phone Creates Opportunities for Villagers in Bangladesh, Published in May 2007

Exhibit Five: Information Technology in Bangladesh

\begin{tabular}{|l|c|c|c|}
\hline & 2000 & 2005 & 2006 \\
\hline Telephone lines (per 100 people) & 0 & 1 & 1 \\
\hline International voice traffic (minutes per person) & 2 & 5 & 6 \\
\hline Mobile cellular subscriptions (per 100 people) & 0 & 6 & 12 \\
\hline Internet users (per 100 people) & 0 & 0 & 0 \\
\hline Personal computers (per 100 people) & 0 & 1 & 2 \\
\hline Households with television (\%) & 18 &.. &.. \\
\hline Fixed broadband subscribers (per 100 people) &.. & 0 &.. \\
\hline $\begin{array}{l}\text { International Internet bandwidth (bits per } \\
\text { person) }\end{array}$ & 0 & 0 & 2 \\
\hline Telecommunications revenue (\% GDP) & 1 &.. &.. \\
\hline $\begin{array}{l}\text { Mobile and fixed-line telephone subscribers per } \\
\text { employee }\end{array}$ & 48 &.. &.. \\
\hline Telecommunications investment (\% of revenue) & 25 &.. &.. \\
\hline $\begin{array}{l}\text { Information and communication technology } \\
\text { expenditure (\% of GDP) }\end{array}$ &.. & 5 & 7 \\
\hline Secure Internet servers (per 1 million people) &.. & 0 & 0 \\
\hline
\end{tabular}

Source: World Bank

\section{Exhibit Six: Telecommunication Industry in Bangladesh}

During 1993-1996, mobile phone customers could not reap the benefits of competition as the market was monopolised by a single company, Pacific Bangladesh Telecom Ltd. Naturally, mobile phone charges were high in this period. However, with the commissioning of mobile phone service by GrameenPhone Limited and Aktel in 1997, the situation started to improve in terms of price reduction and quality.

The period 1997-2004 was characterized by GrameenPhone's dominance. GrameenPhone Limited quickly grabbed the majority market share because of its widespread social network 
(GrameenPhone is a sister organisation of Grameen Bank), and by dint of its high quality network and innovative marketing skills. During 1997-2004, the outcome of competition was suboptimal due to the dominance of one company, but the arrival of Banglalink in the mobile phone market brought immense price competition. The intensity of competition came as a blessing for the customers.

Call charges, which were once very high, went down significantly. The call charges now range between Tk.0.25-2.00/minute, which were in the range of Tk.5-8 before Banglalink's arrival in 2005, and Tk.16/minute in 2001. Moreover, operators now provide a variety of services and promotional packages such as FNF scheme, offpeak rate, free talk time for new connection, loyalty discount on airtime, free sim replacement, club magnate service, "Zem Fun," "pulse billing," etc.

Liberalisation of the sector greatly enhanced tele-density of the country. In March, the total tele-density (fixed + mobile phone) stood at $16 \%$, which was only 0.30 in 1998 and 0.85 in 2005. The present tele-density is still very low compared with global average tele-density of $50 \%$. Availability of the mobile phone has also forced the public sector fixed-telephony provider, BTTB, to adjust its pricing policy. Due to competitive pressures from mobile phones, BTTB recently lowered charges on its different services. The NWD charge has been halved to Tk 1.5 a minute (considering the entire Bangladesh as one zone). Besides, it has also reduced monthly line rent, reinstallation line charge, name and number charge. BTTB land phone users surrendered 40,000 lines in two years (The Daily Star, October 26; Dainik Nayadiganto, October 22). Indeed, the rise of mobile phone is eating away at BTTB's core business of fixed-line voice telephony.

Mobile phones created entrepreneurship among the people. Grameenphone's VPP brought revolutionary changes in the lives of rural people. Village women now earn their livelihood through commodification of a mobile phone. It has also mitigated the social costs by helping wage earners and others who work away from their relatives to be in touch with their beloved and relatives. A recent study reveals that the sector has created 240,000 jobs. 
The mobile phone sector also earns significant amount of Value Added Tax (VAT) for the government, generating Tk.1189.85 crore in FY 2006-07. On balance, the liberalisation of the mobile phone sector has contributed significantly to the socio-economic development of the country. Providing necessary interconnection facilities for mobile phone operators and addressing other problems of the sector are, therefore, of utmost importance.

Source: The Daily Star Article entitled "Liberalisation of the mobile phone sector in Bangladesh" by Mohammad Abu Yusuf and Quamrul Alam Published on 15.11.2007. 